\title{
The Trump Presidency and American Democracy: A Historical and Comparative Analysis
}

\author{
Robert C. Lieberman, Suzanne Mettler, Thomas B. Pepinsky, Kenneth M. Roberts, and \\ Richard Valelly
}

\begin{abstract}
To many observers across the political spectrum, American democracy appears under threat. What does the Trump presidency portend for American politics? How much confidence should we have in the capacity of American institutions to withstand this threat? We argue that understanding what is uniquely threatening to democracy requires looking beyond the particulars of Trump and his presidency. Instead, it demands a historical and comparative perspective on American politics. Drawing on insights from the fields of comparative politics and American political development, we argue that Trump's election represents the intersection of three streams in American politics: polarized two-party presidentialism; a polity fundamentally divided over membership and status in the political community, in ways structured by race and economic inequality; and the erosion of democratic norms. The current political circumstance threatens the American democratic order because of the interactive effects of institutions, identity, and norm-breaking.
\end{abstract}

\section{Trump and the Crisis of Liberal Democracy}

$s$ the United States on the brink of regime change? This possibility was long considered unthinkable in American politics, yet many citizens, activists, pundits, and scholars now actively worry about the state and future of American democracy. Numerous assessments echo this anxiety. As early as 2016, in its annual rating of democracy in 167 countries, for example, The Economist reclassified the United States as a "flawed democracy" (as opposed to a "full democracy"), largely due to eroding public confidence in American political institutions as documented in surveys by Gallup, Pew, and others. ${ }^{1}$ Several surveys of experts have also revealed growing pessimism about the state of American democracy. ${ }^{2}$

Donald Trump's presidency, as it unfolds, amplifies these doubts. First as a candidate and now as president,
Trump openly derides core institutions of democratic governance: the independent press, the judiciary, the bureaucracy, the validity of elections, the legitimacy of democratic contestation, and the centrality of facts to political discourse. He has signaled support for the white nationalist mobilization that has surged since his inauguration. He pursues a governing vision that challenges the hard-won policy and institutional commitments of global democratic liberalism. In international affairs, he clashes with America's strongest democratic allies and obviously admires autocratic rulers. And less than two years into his term, Trump's administration is mired in a criminal investigation by a special counsel into apparent connections between his presidential campaign and the Russian government - and into possible obstruction of justice.

The Trump presidency indeed destabilizes the integrity and resilience of the American political regime and the

Robert C. Lieberman is Krieger-Eisenhower Professor of Political Science at Johns Hopkins University (rlieberman@jhu.edu). Suzanne Mettler is John L. Senior Professor of American Institutions at Cornell University (suzanne.mettler@cornell.edu). Thomas B. Pepinsky is Associate Professor of Government at Cornell University (pepinsky@cornell.edu). Kenneth M. Roberts is Richard J. Schwartz Professor of Government at Cornell University (kr99@cornell.edu). Richard Valelly is Claude C. Smith '14 Professor of Political Science at Swarthmore College (rvalell1@swarthmore.edu).

For helpful comments and suggestions, the authors thank Sheri Berman, Daniel Galvin, Didi Kuo, Joseph Margulies, Paul Pierson, Daniel Stid, Sidney Tarrow, and the participants in the 2017 Workshop on the State of American Democracy in Historical and Comparative Perspective and the 2018 conference, "A Republic, If We Can Keep It," sponsored by the Cornell Center for the Study of Inequality and New America. 
future of liberal democracy in the United States. Voices of concern span the political spectrum, and can be found among voters, activists, and elites. Of course, some more sanguine observers have noted that America's political institutions have faced severe threat before-from the Civil War to the Palmer Raids, from McCarthyism to Watergate-and the American political system managed to recover. ${ }^{3}$ But many wonder whether this time is different. Why is the Trump presidency not seen as a normal-politics challenge to a settled liberal policy order? Why the fear in spite of the legacy of resilience?

Adopting a historical and comparative perspective on American politics, we suggest that the fear is not mere alarmism. We argue that President Trump's election and governance intersect with three conditions in American politics: polarized two-party presidentialism; a polity fundamentally divided over membership and status in the political community; and the erosion of democratic norms at the elite and mass levels. None of these conditions is itself new, but-and this is our critical point-their combination is. These three conditions reinforce and feed off each other; they produce a new configuration that differs from past crisis moments in American politics.

Our aim is to put forward an analytical approach to the Trump presidency that draws insights from the traditions of American political development and comparative politics. A historical and developmental perspective allows us to assess contemporary American politics against earlier episodes of democratic stress, and illuminates the processes of change that have produced this moment and will continue to shape the course of politics in the future. Similarly, cross-national comparison enables us to locate Trump's presidency within a larger global context of rising populist and nationalist challenges to the liberal international order, and to the establishment parties and political elites who constructed it. It also allows us to understand the United States as a case of a larger phenomenon of regime fragility that is well understood among scholars of democratic backsliding and breakdowns. Our argument deliberately places the current political moment in historical and comparative context in order to identify how President Trump's election differs qualitatively from past moments of regime stress, diagnose its origins and antecedents, and chart its possible consequences for American and global politics.

\section{Trump and the 2016 Election}

We turn first to the 2016 election and its aftermath. Some observers focused on Donald Trump himself: a widely disliked and highly polarizing, unconventional, and norm-shattering figure both as a candidate and as president. Others concentrated less on Trump himself and more on the dynamics of the election and the coalition that brought him to power (albeit without even a plurality of the popular vote), interpreting the outcome as a singular rebuke both to politics as usual and to the established American political order. He not only campaigned against many of the foundational policy and political commitments of the global liberal order of the last eighty years or so but also trafficked in a lurid contempt for many of the established patterns and policies of American politics. He repeatedly challenged the very legitimacy of the basic mechanics and norms of the American electoral process, invoking the specter of mass voter fraud, encouraging voter suppression, selectively attacking the Electoral College, and even threatening to disrupt the peaceful transfer of power. Never before in American history has someone been elected president without any previous service in elected office, a cabinet position, or the military. Never in the modern era has a presidential candidate threatened to lock up his opponent; castigated people so publicly and repeatedly on the basis of their country of origin, religion, sex, disability, or military service record; or operated with no evident regard for facts or truth.

Yet in most respects, despite Trump's unconventional campaign, voters followed a predictable partisan script, with the vast majority voting for their party's candidate. ${ }^{4}$ Trump the candidate campaigned in unprecedented ways, but in the event, American voters lined up and mostly voted on partisan lines.

A comparative approach is essential to resolve this quandary. In comparative perspective, populist figures divide the political arena between a virtuous "people," whom they claim to represent, and a venal or incompetent power elite accused of abandoning or betraying "the people." Like many populist leaders, Trump chafes at institutional constraints on his authority, and he projects the belief that he alone can embody the popular will ("I alone can fix it").

At the same time, a long-building developmenthyperpolarization-magnifies tendencies for the partisan capture of institutions that are supposed to exercise checks and balances but may instead be turned into unaccountable instruments of partisan or incumbent advantage. This grafting of authoritarian behavior onto one of the two major parties potentially undermines democratic norms in ways that neither populism nor polarization could do on their own. Moreover, it is nourished by deep racial and economic inequalities and cultural cleavages. From this angle, comparison with other countries that have experienced similar ills is equally essential to a full understanding of the Trump presidency and its threat to democracy.

\section{Liberal Democracy in America: A Historical-Comparative Approach}

Trump's candidacy and his presidency suggest that something fundamental about American politics has changed, implying that basic features of the American democratic regime and the political order that underlies it are at risk 
and that their continuation should not be taken for granted. This observation leads us to historical inquiry for at least two reasons. First, it suggests that we can learn something about the current state of American politics by comparing and contrasting it with earlier patterns of politics, to identify what is new about the current moment and how it might reflect or recapitulate things that have happened before. Second, it suggests that it will be helpful to understand the processes of change (and the forces for stability) that are at work in the current moment and will shape the course of American politics as the Trump administration unfolds. ${ }^{5}$

We draw the concept of a "political order" from American political development: "a constellation of rules, institutions, practices, and ideas that hang together over time ... exhibiting coherence and predictability while other things change around them." Orders define how political actors participate, the roles of individual and collective actors in politics, how political action may legitimately be regulated, and the boundaries of the community itself. Trump's presidency challenges a generally coherent and internally self-reinforcing global liberal order that has framed American politics for decades and that has provided answers to critical questions: how may a presidential candidate behave, what institutions are legitimate and why do we believe them, who may legitimately participate in American political life, and what is America's place in the world?

There are numerous ways of defining the prevailing order and periodizing its rise and fall. The New Deal is the touchstone for this periodization and perhaps one of the two great ruptures, or critical junctures, in American political development (the other being the Civil War and Reconstruction). ${ }^{7}$ The period of the New Deal and World War II, roughly from the early 1930s to the mid-1940s, represents the moment when the United States most decisively broke with its laissez-faire, isolationist, and protectionist past and embraced the architecture of what would become the dominant liberal order of the middle and late twentieth century. The civil rights revolution of the mid-and late century is another building block of the contemporary liberal order. Even the conservative turn in the 1970s and the Reagan revolution that followed largely furthered midcentury liberal internationalism, preserving key elements of New Deal social and economic policy and continuing to promote a stance of global openness and engagement. ${ }^{8}$

An alternative view, to be sure, holds that political "orders" are illusory because institutions and processes operate according to their own logic and on their own temporal scales. However, we see an interplay among several decades-long developments in American politics and society - the remnants of an older industrial political economy confronting the newer, globalized information economy; a welfare state designed to protect against the common risks of an industrial society coping with new post-industrial pressures; and the persistence of racial hierarchies alongside the new commitment to civil rights and racial equality. ${ }^{9}$ These conflicts within the current historical configuration of American politics created the opportunity for diverse anti-establishment social and political movements to emerge, on both the left and right sides of the ideological spectrum - from anti-globalization and Occupy Wall Street protests to the Tea Party and the "birther" movements to the Sanders and Trump campaigns. ${ }^{10}$ These are signs of stresses to the contemporary political order, not a series of disconnected or independent political processes.

A comparative perspective again offers complementary insights into American politics today. Recent experience across Europe, for example, confirms that Trump is not the only contemporary example of right-wing, nativist, protectionist populism in an advanced industrial democracy. ${ }^{11}$ Right-wing ethno-nationalist parties have gained a share of power in Italy and Austria, and they dominate regimes in Hungary and Poland that have progressively whittled away at democratic checks and balances. These movements share many characteristics with the electoral rise of Trump in the United States. Even where right-wing nativist parties have not seized office, they have pulled mainstream parties toward more nationalistic, anti-immigrant stands, and they have reoriented national political debates. ${ }^{12}$ These comparative cases provide more data points than American history alone can provide, and can help identify factors beyond American borders that might help account for Trump's rise and the possible consequences of his presidency.

Comparison also shows that concerns about regime change must be taken seriously. By this we mean some form of democratic breakdown or erosion, a prospect that has long seemed outside the realm of reasonable speculation in the United States, and especially among scholars of American politics. ${ }^{13}$ Comparativists have made substantial progress toward understanding and explaining why democracies emerge and how they fail, and we should attend to their findings. ${ }^{14}$

In the mid-1990s, reacting to the third wave of democratization in the late twentieth century, Adam Przeworski and a group of colleagues argued that "affluence, growth with moderate inflation, declining inequality, a favorable international climate, and parliamentary institutions" were the essential ingredients of democratic stability. ${ }^{15}$ The United States today meets only the first two of those five criteria. More recently, Nancy Bermeo has used "democratic backsliding" to identify a less abrupt but no less consequential form of regime change. ${ }^{16}$ In her account, the days of the coup or massive electoral fraud have been superseded by "executive aggrandizement" and "strategic harassment" of the oppositionboth of which are subjects of intense speculation in 
American politics today. The global political landscape is littered with "hybrid" or competitive authoritarian regimes that possess certain democratic features but systematically violate democratic norms and procedures. ${ }^{17}$ Such regimes stage elections on an uneven playing field; they concentrate power in the hands of a dominant party or leader, whittle away at institutional checks and balances, and restrict the rights of political opponents. Our comparative approach thus draws on knowledge we have gained about regime change, stability, and transition from other countries where these challenges have arisen more frequently.

Pairing the comparative perspective with our historical and development perspective strengthens what we can learn from each. ${ }^{18}$ The rise of Trump describes a historically specific configuration of elements in American politics, but a comparative perspective gives us leverage on what is distinctive about this configuration, and allows us to draw on general theoretical arguments that for too long have been divorced from American politics.

\section{Institutions, Civic Membership and Status, and Norms}

A comparative-historical approach to understanding American democracy requires us, further, to specify what features of American politics are particular to the American context, what features are shared generally across other democratic regimes, how the specific and the general interact, and how these interactions evolve over time to create specific political configurations. ${ }^{19} \mathrm{We}$ propose that there are three distinct but fundamentally interconnected themes that can help account for the current moment in American politics: institutions and institutional design; inequality, especially racial inequality; and norms. We briefly sketch each in turn, connecting current debates in the United States to general concerns in comparative politics and American political development and frame a set of questions for further inquiry.

\section{Institutions}

In comparative terms, political scientists have long noted that American political institutions are unusual, particularly the American brand of presidential government. As Juan Linz has argued, presidential systems are notoriously unstable because they are prone to conflict between separately elected and independently accountable executive and legislative branches. ${ }^{20}$ For Linz, what saved the American political regime from the characteristic fragility of presidentialism was the system of two large "catch-all" parties (a consequence of single-member legislative districts and winner-take-all elections) that tended toward centrism and long kept the most contentious issues of race and inequality off the agenda. Moreover, the United States Congress is, without a doubt, the world's most powerful legislature, wielding independent power that has historically acted as a substantial check on executive authority.
U.S. presidents have few formal constitutional powers, especially relative to other presidential systems.

In recent decades, however, this institutional pattern that seemingly accounted for the stability of the American "presidential" regime has begun to fray. Ideological and partisan polarization, which were at a historically low ebb in the middle of the twentieth century, have dramatically increased to the point where, among political elites, the two parties are farther apart than at any time since the Gilded Age. Both parties have become more ideologically homogeneous, but since the 1980s polarization has been asymmetrical: Republicans have clustered together more in their voting patterns while Democrats remain more diverse. ${ }^{21}$ While the mass public is not as ideologically polarized as are members of Congress, the resurgence of intense, almost tribal, partisanship has hollowed out the middle ground in American politics. Executive power has also grown through the evolution of the administrative and national security states, largely at Congress's expense, eroding one of the distinctive features of American presidentialism. At the same time, polarization and divided partisan control of Congress and the presidency have induced presidents increasingly to try to govern by executive action, with predictably divisive consequences.

In many respects this partisan and ideological polarization set the stage for Trump's rise, as his candidacy channeled the populist, anti-establishment currents nourished by the Tea Party movement that were increasingly dominant at the Republican grass roots in primary election campaigns. Trump clearly exacerbated this polarization, however, with his inflammatory rhetoric, his discrediting of political rivals, and his open contempt for institutional checks on executive power. Increased polarization has "politicized" the control of regime-level institutions like the Supreme Court, the Justice Department, and the FBI, not to mention congressional oversight. In so doing, it has raised the stakes of executive appointments, electoral contests, and the rules that govern them, and it has generated concerns about the willingness of the Republican Party to use congressional and other institutional levers to restrain executive power. The alternative-as the comparative record clearly demonstrates-is to use these institutional levers to protect an executive who advances other core partisan or programmatic objectives. In short, democratic institutions can be used for anti-democratic purposes, and their institutional design alone provides few guarantees against such repurposing.

Trump rose to power in a political system uniquely designed, as we have noted, to fragment and disperse power, with multiple "veto points" where policy change can be blocked or frustrated. ${ }^{22}$ It is here, however, where the combination of Trump's autocratic tendencies with partisan and ideological polarization instead challenge the resilience of the American democratic regime; simply put, this combination increases the risk that regime institutions 
will be manipulated and turned into instruments of partisan advantage. Thus the Trump phenomenon is both a consequence of a historically specific configuration of fragile institutions and a growing force, in itself, that has the potential to reshape the very institutional architecture of American politics.

\section{Civic Membership and Status: How Race and Inequality Matter}

Trump has legitimized and ushered back into the foreground of American politics contestation over core questions of civic membership and status: who is included in the political community and what are their participatory rights? Throughout American political history, liberal ideals have existed in conflict with "ascriptive American traditions." 23 Such contestation, whether over race, gender, ethnicity, religion, or other identities, is a defining feature of American politics.

In a foundational 1970 article, Dankwart Rustow overturned what had been a prevailing consensus about the preconditions for democracy. Rather than looking for particular configurations of mass public opinion, socioeconomic conditions, or political institutions, as modernization theory suggested, he proposed that democratic transitions depend on the processes by which political elites and social forces negotiate the terms of democratic transition. For Rustow, there was but one precondition for democracy to emerge and endure: national unity, or broad agreement about the boundaries of the political community. ${ }^{24}$ Without that agreement about who may participate in democratic procedures, citizens cannot rely on those procedures to generate democratic outcomes.

In the American context, since the founding, conflict over civic membership and status has been shaped profoundly by the racial structure of American society. Here the decades of slavery and the restoration of white supremacy around the turn of the twentieth centuryamid party elite consensus that biracial democracy during and after the Reconstruction was a major policy mistakeare crucial influences in American political development. They shaped electoral and policymaking institutions, party alignments and strategy, mass popular opinion, and the stakes for inclusive and participatory politics. ${ }^{25}$ Race is a fundamental axis of conflict organizing civic membership and status in American politics, and is plainly central to the problem of national unity that Rustow considered the sole precondition for democracy. ${ }^{26}$

For these reasons, challenges to the citizenship and participatory rights of minority groups, not just African Americans, amount to a challenge to democracy itself. In many instances, would-be authoritarian leaders challenge the legitimate participatory rights of their opponents by claiming that their exercise of democratic rights itself undermines national unity. Historically, regimes have deemed opponents antithetical to the national community on the basis of their political views (communism, for example), or identity characteristics (LGBTQ or secularism, among others). It is also possible to see such processes at work in American politics, particularly in the way race has, over time, affected the boundaries of membership in the American political community, particularly the right to vote. ${ }^{27}$ Voting rights remain at risk today due to the hollowing out of the Voting Rights Act, voter suppression efforts designed to eliminate elusive "voter fraud," and policies such as felon disenfranchisement that demonstrably shape election outcomes and limit black empowerment. $^{28}$

While racial identity has long been one of the fundamental cleavages of American politics, parties have varied over time in the extent to which they have mobilized racial cleavages and sorted along racial lines. At some times, cleavages other than race, such as class, have dominated American politics and party alignments. But when racial issues have been highly salient or racial voting patterns highly divergent (or both), American political parties have tended to choose up sides. For much of the twentieth century, the racial lines between the parties were relatively indistinct, as neither party sought seriously to challenge Jim Crow or other structures of segregation-Democrats because they were divided between southern and northern factions and Republicans because they had little electoral incentive to declare themselves on either side. Since the 1960s, the parties have sharply divided along racial lines over issues, constituencies, and electoral appeals. ${ }^{29}$ At the same time, racial antagonism and conflict slowly deepened, as manifest in rising activity and visibility of white supremacist hate groups and growing conflict between white police officers and African-American communities, among other trends, and, of course, President Trump's own inflammatory rhetoric. ${ }^{30}$

President Trump's embrace of racial animosity is thus the consequence of a generation of structural trends in racial politics. ${ }^{31}$ The rising salience and politicization of racial, ethnic, and religious cleavages have opened the door to a populist leader who will draw the definition of who "the people" are in a way that mobilizes resentment and licenses disenfranchisement.

Trump's nativist and race-laden populism connects, as well, to mass distrust of the public sector. ${ }^{32}$ Although Americans continue to rely on the federal government more than ever before to ensure economic security and educational opportunity, trust in government has eroded dramatically. This disconnect between government and citizens-fueled by strong partisanship, distrust in government, and negative attitudes about welfare-tends to override the impact of policy experiences in shaping political preferences and behavior. ${ }^{33}$ The divergence of fortunes across the economic spectrum and the disconnect between what government actually does and citizens' 
perceptions of it have intensified distinctions among a set of political identities that have increasingly hardened into almost tribal conflict: not only across racial and ethnic lines but also urban versus suburban versus rural; industrial versus post-industrial; native versus immigrant; regional; and, perhaps above all, partisan. ${ }^{34}$

\section{Democratic Norms}

Finally, the long-term stability of American politics depends on a set of norms, or commonly held but often informal understandings that govern behavior even when formal rules do not delineate politicians' behavior. ${ }^{35}$ These norms include mutual respect across party lines within the legislature, tolerance of vigorous political dissent, and respect for the legitimacy of elections, among many others. Democracy is, first and foremost, a set of rules and procedures for waging and managing conflict by institutionalized means. The framers of the United States Constitution deliberately designed institutional machinery that would structure and routinize the contest for power and fragment and check political power, in order to prevent the emergence of a dictatorial ruler or a faction that aimed to usurp the rights of other citizens. The framework of this machinery has changed little over more than two centuries. Yet these institutional restraints are only as strong as the norms that undergird them, binding political leaders to routinized patterns of behavior and instilling in citizens expectations about how democratic governance is to be carried out. In the United States, critical democratic norms-including principles and practices of racial and gender equality, press freedom, and fair and open political competition-emerged only over time. Suffrage rights have continually roiled American politics.

Recent developments raise questions about whether and to what extent norms governing and safeguarding the basic practices of democratic self-government have actually fully taken hold in the United States. The founders did not themselves develop ideas about the importance of political competition, the legitimacy of political opposition, or the importance of an independent press to a well-functioning political system. Executive-branch norms emerged only haltingly. The Electoral College nearly broke down as soon as George Washington, the country's consensus choice for founding leadership, ceded the political stage and his lieutenants clashed over his mantle and legacy. The Alien and Sedition Acts of 1798 sought to delegitimize and even criminalize political opposition. And the partisan press of the 1790s made the cable news wars of the twenty-first century look like a well-mannered garden party. ${ }^{36}$ Today, however, claims of "not my president" have become increasingly commonplace among partisans of both stripes, starting with liberals referring to George W. Bush, progressing to the "birther" bandwagon that questioned whether President Obama was born in the United States, and now once again with the insistence that President Trump be impeached.
Other norms have arisen to govern the functioning of Congress. For example, congressional behavior long emphasized comity and mutual respect across party lines that facilitated the formation of cross-partisan lawmaking coalitions, a norm that was reinforced by relative party weakness and relatively diffuse partisan identity among voters. ${ }^{37}$ This norm has been eroding for several decades, increasingly supplanted by what Frances Lee has called "teamsmanship," an approach to legislating that placed a high premium on intra-partisan cooperation and loyalty. ${ }^{38}$ This trend has had a number of consequences: the increasing use of the filibuster as a routine tactic to block legislation; regular standoffs over government shutdowns and the once-routine raising of the federal debt limit; and Senate Republicans' yearlong refusal to entertain President Obama's nominee to fill a vacancy on the Supreme Court. The breakdown of such norms of legislative structure and process risk the possibility of legislative illegitimacy, the further strengthening of the executive branch and heightening the contradictions of "dual legitimacy" that Linz identified as inherent in all presidential systems. ${ }^{39}$ By imposing some measure of restraint on office holders, the ordinary norms of legislative processes have so far prevented office holders from deploying the full measure of an institution's authority to harass or eliminate political opponents. "In fact," write Robert Mickey, Steven Levitsky, and Lucan Way, "the systematic underutilization of power by presidents and congressional majorities has long served as a vital source of democratic stability in the United States." 40

American office holders have not, as a rule, sought to undermine the very legitimacy of their political opponents-a norm that draws on our preceding discussion of political community and democratic stability. When American politicians have engaged in this kind of behavior-Abraham Lincoln's suspension of civil liberties during the Civil War, for example, or the excesses of McCarthyism, or Richard Nixon's illegal machinations that led to the Watergate scandal-other actors in the political system have generally called them to account. But these actors did so not out of institutional necessity, but because they adhered to a set of norms about liberal political competition and the normative limits of executive power. When politicians no longer observe such norms, the checks and balances of American political institutions are not self-executing. The result may be a system with the trappings of democracy-elections and the appearance of contestation for power-but without the safeguards that ensure true democratic governance and protect citizens from predation and oppression, such as universal suffrage and civil liberties. ${ }^{41}$ Such seems to have been the fate over time of countries in Latin America such as Venezuela under populist leader Hugo Chávez and his successors, as well as in European countries such as Turkey, Poland, and Hungary. 
One may argue that the patterns of behavior that we call "norms" are not really constraints on politicians' behavior. Officeholders may accept limits on their own behavior and restraints on their power only when it is in their interest, when transgressing those limits would result in worse outcomes from their point of view. ${ }^{42}$ For example, Republicans in Congress express obvious displeasure with President Trump, but have not directly confronted him on questions of his and his family's conflicts of interest, possible collusion with Russia, or possible obstruction of justice. But it may also be that they act this way because they believe that their electoral or policy interests (or both) are best served by supporting him, and that once they see those interests better served without him they will drop him, as Republicans only belatedly (and abruptly) dropped Richard Nixon in the denouement of the Watergate scandal.

Although norms-based arguments can be analytically slippery, we view the erosion of democratic norms as essential to characterizing just what it is about the current political moment that threatens American democracy. Plainly, it is norms about presidential behavior that President Trump has so violated, and it is the very precedent of their violation that calls into question other established practices of American democracy. ${ }^{43}$

\section{Contemporary Democracy in America: An Evaluation}

A comparative and historical perspective on contemporary American politics enables us to diagnose the current challenges facing American politics as symptoms of larger historical processes that have analogues in cross-national experiences. The challenges to American democracy are revealed by President Trump's candidacy and election, but cannot be reduced to the man himself or to the contemporary circumstances of a single election. Rather, in a presidential system characterized by a fundamental cleavage over racial identity and undergoing sharply rising economic inequality, an outsider candidate has gone some distance toward exploiting the dual-legitimacy problem that Linz singled out as the Achilles' heel of presidential systems. Executive norm-breaking continues at a breathtaking pace, with an increasingly partisan divide over whether or not the president ought to be held to account.

We are now in the position to tackle the questions that we raised in the introduction. Is American democracy under threat? Our answer is yes: comparative experience suggests that these are not propitious conditions for democratic durability, and certainly not for effective government performance. How serious is the threat? It is hard to argue that contemporary American democracy faces a more acute threat than it did during the Civil War. But systematic disenfranchisement of American voters, or the use of executive power against regime critics, now seem disturbingly plausible. What is the nature of that threat? Our framework considers institutions, the boundaries of civic membership and status, and norms as bearing an interactive relationship to one another. The sorting of parties in a racialized polity has enabled a certain type of exclusionary politics in a far more presidential regime. This kind of interactive complexity raises the stakes for democratic stability, for it enables the corrosion of norms of executive restraint, with possibly broader repercussions for campaign strategy and voter mobilization around exclusionary white nationalist motifs.

What, then, does the future hold? Politics will matter, in ways that are hard to predict. The defense of norms and institutions of inclusive citizenship will be exceptionally important as we go forward, for example, as will debates about how to address the corrosive effects of rising inequality. Indeed, all of the norms and institutions that we discussed will require defense and renewal. The very scope of the challenge underscores the gravity of the current moment — and the need to be open to lessons from other national and political histories that once seemed of little relevance to the American experience.

\section{Notes}

1 Economist Intelligence Unit 2016.

2 See, for example, the Bright Line Watch project (brightlinewatch.org) and the Authoritarian Warning Survey (https://www.authwarningsurvey.com). See also Frum 2018.

3 See, for example, Fukuyama 2017.

4 For elaboration, see Lieberman et al. 2017.

5 Skocpol 2016.

6 Orren and Skowronek 2004, 14-15. See also Lieberman 2002, 802; Plotke 1996, 1.

7 See Collier and Collier 1991; Capoccia and Kelemen 2007.

8 Fraser and Gerstle 1989; Plotke 1996.

9 Pierson 2001.

10 See Skocpol and Williamson 2012; Parker and Barreto 2013.

11 See Roberts 2016.

12 Mudde 2013.

13 Some works have explicitly understood American democracy as a fragile and unfinished project. See, for example, Katznelson 2003; Valelly 2004; King et al. 2009; Mickey 2015.

14 For a recent review, see Lust and Waldner 2015.

15 Przeworski et al. 1996.

16 Bermeo 2016.

17 Levitsky and Way 2010.

18 See Pierson 2007.

19 See Katznelson 1997.

20 Linz 1990.

21 McCarty, Poole, and Rosenthal 2006; Mann and Ornstein 2012. 
22 Tsebelis 2002.

23 Smith 1997.

24 Rustow 1970.

25 Valelly 2004; King and Smith 2011; Mickey 2015.

26 Similar arguments have been made about gender. See Mettler 1998; Ritter 2006.

27 Valelly 2004; King et al. 2009; Mickey 2015.

28 Shelby County v. Holder 2013; Uggen and Manza 2002.

29 Carmines and Stimson 1989; Schickler 2016; Tesler 2016.

30 Potok 2017.

31 King and Smith 2011, 2017.

32 Weaver 2016; Derthick and Quirk 1985.

33 Mettler 2011, 2018; Gilens 1995; Schram, Soss, and Fording 2003.

34 McAdam and Kloos 2014; Achen and Bartels 2016; Sunstein 2015.

35 See Thelen 1999; Helmke and Levitsky 2004.

36 Elkins and McKitrick 1993.

37 Arnold 1990.

38 Lee 2009, 2016; Mann and Ornstein 2012.

39 Binder 2015; Linz 1990.

40 Mickey, Levitsky, and Way 2017, 24. See also Levitsky and Ziblatt 2018; Bermeo 2016.

41 Levitsky and Way 2002; Zakaria 2003. See also Bermeo 2016.

42 Weingast 1997, 1998.

43 See McAdams 1997; Levitsky and Ziblatt 2018.

\section{References}

Achen, Christopher H. and Larry M. Bartels. 2016. Democracy for Realists: Why Elections Do Not Produce Responsive Government. Princeton, NJ: Princeton University Press.

Arnold, R. Douglas. 1990. The Logic of Congressional Action. New Haven, CT: Yale University Press.

Bermeo, Nancy. 2016. "On Democratic Backsliding." Journal of Democracy 27(1): 5-19.

Binder, Sarah. 2015. "The Dysfunctional Congress." Annual Review of Political Science 18: 85-101.

Capoccia, Giovanni and R. Daniel Kelemen. 2007. "The Study of Critical Junctures: Theory, Narrative, and Counterfactuals in Historical Institutionalism." World Politics 59(3): 341-69.

Carmines, Edward G. and James A. Stimson. 1989. Issue Evolution: Race and the Transformation of American Politics. Princeton, NJ: Princeton University Press.

Collier, Ruth Berins and David Collier. 1991. Shaping the Political Arena: Critical Junctures, the Labor Movement, and Regime Dynamics in Latin America. Princeton, NJ: Princeton University Press.

Derthick, Martha and Paul J. Quirk. 1985. The Politics of Deregulation. Washington, DC: Brookings Institution.
Economist Intelligence Unit. 2016. "Democracy Index 2016: Revenge of the 'Deplorables'." Available at http://www.eiu.com/Handlers/WhitepaperHandler. ashx?fi=Democracy-Index-2016.pdf\&mode $=$ wp $\&$ campaignid $=$ DemocracyIndex2016; accessedd October 26, 2017.

Elkins, Stanley and Eric McKitrick. 1993. The Age of Federalism: The Early American Republic, 1788-1800. New York: Oxford University Press.

Fraser, Steve and Gary Gerstle, eds. 1989. The Rise and Fall of the New Deal Order, 1930-1980. Princeton, NJ: Princeton University Press.

Frum, David. 2018. Trumpocracy: The Corruption of the American Republic. New York: Harper.

Fukuyama, Francis. 2017. "Is American Democracy Strong Enough for Trump? The Case Against Panic." Politico, January 23. Available at http://www.politico. $\mathrm{com} / \mathrm{magazine} /$ story/2017/01/donald-trumpamerican-democracy-214683; accessed October 26, 2017.

Gilens, Martin. 1995. Why Americans Hate Welfare: Race, Media, and the Politics of Antipoverty Policy. Chicago: University Press.

Helmke, Gretchen and Steven Levitsky. 2004. "Informal Institutions and Comparative Politics: A Research Agenda." Perspectives on Politics 2(4): 725-40.

Katznelson, Ira. 1997. "Structure and Configuration in Comparative Politics." In Comparative Politics: Rationality, Culture, and Structure, ed. Mark Irving Lichbach and Alan S. Zuckerman. Cambridge: Cambridge University Press.

- 2003. Desolation and Enlightenment: Political Knowledge After Total War, Totalitarianism, and the Holocaust. New York: Columbia University Press.

King, Desmond, Robert C. Lieberman, Gretchen Ritter, and Laurence Whitehead, eds. 2009. Democratization in America: A Comparative-Historical Analysis.

Baltimore, MD: Johns Hopkins University Press.

King, Desmond S. and Rogers M. Smith. 2011. Still a House Divided: Race and Politics in Obama's America. Princeton, NJ: Princeton University Press.

2017. "A New Era for Old Racial Policy Alliances:

The Trump Coalition.” Presented at the annual meeting of the American Political Science Association, San Francisco, August 31-September 3.

Lee, Frances E. 2009. Beyond Ideology: Politics, Principles, and Partisanship in the U.S. Senate. Chicago: University of Chicago Press.

2016. Insecure Majorities: Congress and the Perpetual Campaign. Chicago: University of Chicago Press.

Levitsky, Steven and Lucan A. Way. 2002. "Elections Without Democracy: The Rise of Competitive Authoritarianism." Journal of Democracy 13(2): 51-65. 
2010. Competitive Authoritarianism: Hybrid Regimes After the Cold War. New York: Cambridge University Press.

Levitsky, Steven and Daniel Ziblatt. 2018. How Democracies Die. New York: Crown.

Lieberman, Robert C. 2002. "Ideas, Institutions, and Political Order: Explaining Political Change." American Political Science Review 96(4): 697-712.

Lieberman, Robert C., Suzanne Mettler, Thomas B. Pepinsky, Kenneth M. Roberts, and Richard Valelly. 2017. "Trumpism and American Democracy: History, Comparison, and the Predicament of Liberal Democracy in the United States." Social Science Research Network. Available at https://papers.ssrn. com/sol3/papers.cfm?abstract_id=3028990; . accessed July 31, 2018.

Linz, Juan J. 1990. “The Perils of Presidentialism.” Journal of Democracy 1(1): 51-69.

Lust, Ellen and David Waldner. 2015. "Unwelcome Change: Understanding, Evaluating, and Extending Theories of Democratic Backsliding." United States Agency for International Development. Available at http://pdf.usaid.gov/pdf_docs/PBAAD635.pdf; accessed October 26, 2017.

Mann, Thomas E. and Norman J. Ornstein. 2012. It's Even Worse Than It Looks: How the American Constitutional System Collided with the New Politics of Extremism. New York: Basic Books.

McAdam, Doug and Karina Kloos. 2014. Deeply Divided: Racial Politics and Social Movements in Postwar America. Oxford: Oxford University Press.

McAdams, Richard H. 1997. "The Origins, Development, and Regulation of Norms." Michigan Law Review 96(2): 338-433.

McCarty, Nolan, Keith T. Poole, and Howard Rosenthal. 2006. Polarized America: The Dance of Ideology and Unequal Riches. Cambridge: MIT Press.

Mettler, Suzanne. 1998. Dividing Citizens: Gender and Federalism in New Deal Public Policy. Ithaca, NY: Cornell University Press.

- 2011. The Submerged State: How Invisible Government Policies Undermine American Democracy. Chicago: University of Chicago Press.

. 2018. The Government-Citizen Disconnect. New York: Russell Sage Foundation.

Mickey, Robert. 2015. Paths Out of Dixie: The Democratization of Authoritarian Enclaves in America's Deep South, 1944-1972. Princeton, NJ: Princeton University Press.

Mickey, Robert, Steven Levitsky, and Lucan Ahmad Way. 2017. "Is America Still Safe for Democracy? Why the United States Is in Danger of Backsliding." Foreign Affairs 96(May/June): 20-29.

Mudde, Cas. 2013. "Three Decades of Radical Right Parties in Western Europe: So What?," European Journal of Political Research 52(1): 1-19.
Orren, Karen and Stephen Skowronek. 2004. The Search for American Political Development. Cambridge: Cambridge University Press.

Parker, Christopher S. and Matt A. Barreto. 2013. Change They Can't Believe In: The Tea Party and Reactionary

Politics in America. Princeton, NJ: Princeton University Press.

Pierson, Paul, ed. 2001. The New Politics of the Welfare State. Oxford: Oxford University Press.

- 2007. "The Costs of Marginalization: Qualitative Methods in the Study of American Politics." Comparative Political Studies 40(2): 145-69.

Plotke, David. 1996. Building a Democratic Political Order: Reshaping American Liberalism in the 1930s and 1940s. Cambridge: Cambridge University Press.

Potok, Mark. 2017. "The Year in Hate and Extremism." Southern Poverty Law Center. Available at https:// www.splcenter.org/fighting-hate/intelligence-report/ 2017/year-hate-and-extremism; accessed October 27, 2017.

Przeworski, Adam, Michael Alvarez, José Antonio Cheibub, and Fernando Limongi. 1996. "What Makes Democracies Endure?” Journal of Democracy 7(1): 39-55.

Ritter, Gretchen. 2006. The Constitution as Social Design: Gender and Civic Membership in the American Constitutional Order. Stanford, CA: Stanford University Press.

Roberts, Kenneth M. 2016. "Populism as Epithet and Identity: The Use and Misuse of a Contested Concept." Comparative Politics Newsletter 26(2): 69-72.

Rustow, Dankwart. 1970. "Transitions to Democracy: Toward a Dynamic Model." Comparative Politics 2(3): 337-63.

Schickler, Eric. 2016. Racial Realignment: The Transformation of American Liberalism, 1932-1965. Princeton, NJ: Princeton University Press.

Schram, Sanford F., Joe Soss, and Richard F. Fording, eds. 2003. Race and the Politics of Welfare Reform. Ann Arbor: University of Michigan Press.

Shelby County v. Holder. 2013. 570 U.S. 2.

Skocpol, Theda. 2016. "Analyzing American Political Development as It Happens." In The Oxford Handbook of American Political Development, ed. Richard M. Valelly, Suzanne Mettler, and Robert C. Lieberman. Oxford: Oxford University Press.

Skocpol, Theda and Vanessa Williamson. 2012. The Tea Party and the Remaking of Republican Conservatism. Oxford: Oxford University Press.

Smith, Rogers M. 1997. Civic Ideals: Conflicting Visions of Citizenship in U.S. History. New Haven, CT: Yale University Press.

Sunstein, Cass R. 2015. "Partyism." University of Chicago Legal Forum, Article 2. 
Tesler, Michael. 2016. Post-Racial or Most-Racial? Race and Politics in the Obama Era. Chicago: University of Chicago Press.

Thelen, Kathleen. 1999. "Historical Institutionalism in Comparative Politics." Annual Review of Political Science 2: 369-404.

Tsebelis, George. 2002. Veto Players: How Political Institutions Work. Princeton, NJ: Princeton University Press.

Uggen, Christopher and Jeff Manza. 2002. "Democratic Contraction? Political Consequences of Felon Disenfranchisement in the United States." American Sociological Review 67(6): 777-803.

Valelly, Richard M. 2004. The Two Reconstructions: The Struggle for Black Enfranchisement. Chicago: University of Chicago Press.
Weaver, Timothy P. R. 2016. Blazing the Neoliberal Trail: Urban Political Development in the United States and the United Kingdom. Philadelphia: University of Pennsylvania Press.

Weingast, Barry R. 1997. "The Political Foundations of Democracy and the Rule of Law." American Political Science Review 91(2): 245-63.

1998. "Political Stability and Civil War: Institutions, Commitment, and American Democracy." In Analytic Narratives, ed. Robert H. Bates, Avner Greif, Margaret Levi, Jean-Laurent Rosenthal, and Barry R. Weingast. Princeton, NJ: Princeton University Press. Zakaria, Fareed. 2003. The Future of Freedom: Illiberal Democracy at Home and Abroad. New York: W.W. Norton. 